\title{
A Brief History of Legal Comparison: A Lesson from the Ancient to Post-Modern Times
}

\author{
Roberto Scarciglia \\ Department of Political and Social Sciences, University of Trieste, Trieste, Italy \\ Email: roberto.scarciglia@dispes.units.it
}

Received 10 November 2015; accepted 12 December 2015; published 15 December 2015

Copyright (C) 2015 by author and Scientific Research Publishing Inc.

This work is licensed under the Creative Commons Attribution International License (CC BY). http://creativecommons.org/licenses/by/4.0/

(c) (i) Open Access

\begin{abstract}
This essay offers a reconstruction of the historical evolution of legal comparison from the ancient to post-modern times. In particular, the author wishes to focus on the most important legal scholars and their contribution to the creation and development of comparative law and its methodology. Comparison of rules or constitutions has ancient origins and every age has left a legacy. For this reason, the Author has divided this essay into nine periods: the Ancient World, the Middle Ages, the Renaissance, the Seventeenth and Eighteenth Centuries, the Nineteenth Century, from the Congress in Paris, 1900, to the first half of the Twentieth Century; the second half of the Twentieth Century. To claim legal comparison as the result of its history is also to acknowledge that most of the today's scholars have learned the lesson of the ancients masters of legal comparison.
\end{abstract}

\section{Keywords}

Legal Comparison, Legal History, Comparative Law

\section{Introduction}

"History involves Comparison”. Maitland's famous words indicate the close relationship between history and comparison (Maitland, 1911), but the same can be said of the opposite, "Comparison involves History" (Gorla, 1964). The definitions quoted below stress the importance of a legal culture open towards a circulation of ideas and values belonging to one legal system or another. From the origins of legal comparison, historical studies were far from the analysis of foreign legislation and historical references were as tinsel without function. Of course, legal history does not represent the principal aim of comparative enquiry, but the eye of a comparatist looks at a historical fact, beyond legal classification, with freedom, without prejudice, and whether it is a matter 
of autochthonous law, as of foreign law. From this point of view, for example, it is possible to consider cultural experiences as conceptualism, dogmatism or the study of Pandects only as if they were historical facts. A Common Law jurist should have the same attitude (Gorla, 1964), as if he comes from different cultural back grounds. Knowledge of the law which is not satisfied with being superficial, "will involve satisfaction for historical investigation and a remarkable sensibility towards everything concerning the development and evolution of history" (Bognetti, 1994). Also, how could we thoroughly understand the term "equity" or "writ", without knowing English history? Further, what value could "mixed legal systems" have, as is the case of Israel or Puerto Rico, perceived without special knowledge of the evolution of these legal systems? One of the most important French jurists, Adhémair Esmein (1848-1913), argues that it is necessary to use a methodology, legal history and legal comparison to understand the complex structure of the legal institutions (Esmein, 2001). On the other hand, the legal comparison is different from the history of law, "as history is in each historical event in itself (every legal system as a historical fact). Therefore, this historical fact could be both a term of comparison (for example, French law or Italian law) and what is a common element as a working hypothesis in comparison (for example, the Roman origins of continental law). This distinction does not exclude the history coming together of comparison. On the one hand, we certainly cannot understand a historical fact without putting it about others; on the other, it is not possible to identify each term of comparison without knowing its history when the same is necessary for comparative analysis.

According to Hug, comparative law (strictu sensu) involves at least two different points of view: on the one hand, we may compare foreign systems with domestic systems, and on the other, we may consider "the causal relationship between different systems of law of various legal systems", also from a diachronic point of view. In its turn, comparative legal history would also integrate different perspectives as well: on one side, comparative legal history (strictu sensu) compares the history of two or more legal systems, as much in its causal relationship as in its different phases of evolution. From another point of view, there is an universal history of law which draws up the development of existing legal institutes and the evolution of law in relation to its historical periods and to legal systems (Hug, 1932). We believe that "History, separated from the living document, is not a spiritual expression, but only an idea, a combination of other signs" (Croce, 1943). Even if the writer is not a historian, the purpose of this Article can justify a brief description of the most crucial stages for the consolidation of the science of comparative law and to point out the most famous protagonists in each stage of its evolution: our legacy for developing comparative law (Riles, 2001). For this reason, the Author has divided this essay into nine periods: the Ancient World, the Middle Ages, the Renaissance, the Seventeenth and Eighteenth Centuries, the Nineteenth Century, from the Congress in Paris, 1900, to the first half of the Twentieth Century; the second half of the Twentieth Century and beyond.

\section{The Ancient World}

Comparison of rules or constitutions has ancient origins and every age has left a legacy. In this Article, reference is only to the most prestigious experiences of comparison in the history of law. An indispensable methodological characteristic of all comparative studies, in the modern sense, begins to be outlined according to the opinion extended in the International Congress of Comparative Law, celebrated in Paris in 1900 during the Universal Exhibition.

The first period—-"The Ancient World"—had its beginning with the consolidation of superior laws and for the prestige that the process of imitation or legal transplant fostered (Hug, 1932). The most famous lawmakers in the Ancient World were Lycurgus of Sparta (776 B.C., according to Aristotle), Draco of Athens (624 B.C.) and Solon of Athens (born around 594 B.C.). Despite the uncertainty about their lives and legal codes, it is important to underline that they travelled for many years, to visit those foreign States where better laws were established. It could therefore say that legal comparison began with the journeys of the ancient law scholars. All in all, legal comparison is a travel and the comparatist is a traveler, "He travels only to return. He then travels to tell. He travels to understand himself and others" (Lupoi, 2001). None of the ancient legislations was, however, important as the laws of the Twelve Tables of Rome, which became a model in many countries, unlike other codes issued at an earlier age. According to Henry Sumner Maine, "[i]t is, indeed, true that the Twelve Tables of Rome do exhibit some traces of systematic arrangement, but this is probably explained by the tradition that the framers of that body of law called in the assistance of Greeks who enjoyed the later Greek experience in the art of law-making” (Maine, 1861). 
These old legislations constituted moral rules and its purposes were rather "the practical triumph of absolute law" than the conviction to use them as a comparison, in the sense we use of mean (Amari, 1857). "Historians and poets, although they were the first compilers of comparative legislation, do not announce anything general or scientific, except the common and vague intention of satisfying a closer interest in these men who should have known each other. [...] Nevertheless, one day, a verse of Homer or a word of Herodotus [...] are like a documents that prove the existence of fundamental laws, concerning towns and families that will invoke it like articles of a venerable code" (Amari, 1857). Therefore, it is possible to find other legal references in Plato's Timeous and Dialogues or in Aristotle's Politics as a chronicle of trips or a comparison between norms and constitutions of the most important states of the Ancient World (Crete, Athens and Sparta). The study of the laws of other States did not mean, however, a comparison in the sense that we know today. The only operations of comparison as "systematic work" were the Collatiolegum Romanorum et Mosaicarum-a collection of legal fragments by Paul, Ulpian, Papinianus, Modestinus and others, probably in the IV ${ }^{\text {th }}$ century B.C. They compared these legal texts with the norms of Mosaic legislation, with the purpose of demonstrating the compatibility between Roman law and the prescriptions of the Bible.

Roman jurists show an interest for foreign law until the Constitution of Antoninus, or Edict of Caracalla (212 A.C.) that extended the Roman law to all persons, eliminating conflicts between sources of law and plurality of legal systems. Nevertheless, it is not possible to argue that, until the Constitution of 212 D.C., a comparison between laws existed through a systematic methodology. The same Jus gentium, created by the Pretor peregrinus-who oversaw the controversies between foreigners or these and Roman citizens — was "the empirical outcome of the administrative procedure to improve the law also for non-Roman citizens.” (Sarfatti, 1933). The creation of codes and their circulation as a model of prestige or authority has not only affected the western world. In this regard, we can recall the Laws of Manu (about 220 B.C.), one of the first written codes of Asia, which represented the model to which British colonists inspired themselves to introduce Hindu Law.

\section{The Middle Ages}

The second period includes all the Middles Ages, from the fall of the Roman Empire of the West (476 D.C.) - from which "the creative age of Italian law started"-until the Renaissance. Moreover, the permanent absence of efficient legal studies prevented the development of comparison, which was in elemental form as it was in the Ancient World. It had to wait some centuries until the first comparative law book. However, the Barbarian invasions produced a great interest in the laws of the conquerors. These laws produced antinomies with the Roman law, particularly for the harmonization of Lombard law and the Roman tradition. Lombard lawenforced during a long period in the countries of Southern Italy, became a territorial law in Benevento, Capua, Salerno and in Apulia, in spite of the opposition of the faithful adherents to the Roman tradition. The principles of Lombard and Roman law were objects of comparison, as, for example, the works of Carlo of Tocco from Benevento, master in Bologna (who lived between the XII ${ }^{\text {nd }}$ and XIII ${ }^{\text {th }}$ centuries). He wrote the famous Glossa Lombarda (1215), a reference model in the Italian law schools and Courts. We can also point out Andrea Bonello from Barletta (1200-1271 or 1291), who wrote a short treaty to reduce to a minimum the use of the Lombard law, in which he pointed out the differences (De differentiis inter ius Langobardorum et Romanorum, 1265).

The teaching and the development of the law-and, therefore, also the issue of operations of comparisonwere strictly in connection with the development of the universities that represented "one of the most original and fecund creations of civilization in the Middle Ages” (Verger, 1999). Particularly, regarding the teaching of law, we can point out that Italian universities, and mainly the Schools of Bologna, Padua and Pisa, were centers of attraction for clerics and lay people coming from other countries, who wished to participate in the master classes of law. These universities promoted the study of Roman and canonic law. After the publication of the Bull Super speculum, the Pope Honorius III, in 1219, only permitted the teaching of canonic law.

From 1346, the Studia generalia were those of Bologna, Paris, Montpellier, Cambridge, Salamanca, Padua, Naples, Vercelli, Tolosa, Lisbon and Lérida (pontifical university). Afterwards, in other universities within Europe, there were chairs of Roman law, canonic law and feudal law, as in Prague, founded by Charles the Fifth in 1348, Vienna in 1356, Heidelberg in 1386, Cologne in 1388 and Erfurt in 1392. Concisely, we can remember that, in Europe, the structure of these Studia generalia presented remarkable peculiarities. In the South, the Bolognese model prevailed with the teaching of civil and canonic law (Le Goff, 1979), whereas, in the north of 
Europe, the Parisian model was dominant and imitated, in Oxford and Cambridge, and it well characterized the studies for the canonic law. In 1219, Roman law was followed in Paris, while, in England, the evolution of Common Law had made the need to learn this law (Verger, 1999). We can remember that during $\mathrm{XV}^{\text {th }}, \mathrm{XVI}^{\text {th }}$ and $\mathrm{XVII}^{\text {th }}$ centuries, the common law was a peculiarity of university legal education in all Europe; known and disclosed in a universal language, Latin, contributed to reinforcing the tendency to the unification of the European legal systems. The use of the language, the common methodological development and the preliminary studies for a university, allowed that the teaching of law would have homogenous characteristics in Central and Western Europe.

Until the beginning of $\mathrm{XV}^{\text {th }}$ century, in the most prestigious universities, there was a renewal of the branches of the law, particularly in Italian universities, under the influence of the works of Giovanni de Andrea, Bartolus of Sassoferrato and Baldus de Ubaldis_-and in Toulouse. The reputation of Bartolus was so great that, in Padua, the consequence was the creation of a Chair dedicated to the Glossa of Accursius and Bartolus, whereas, in Spain and Portugal, the law decreed that, in the cases of divergence between interpreters, the Opinio Bartoli prevailed in any case. Handling for the first time norms of different branches of law (Roman, canonic, feudal and the statutes of cities), these jurists contributed to the unification of the law and the adaptation to the functional and normative needs in the last part of the Middle Ages. Moreover, they favored the circulation and the study of the experiences of customary law and, so, the appearance of problems of comparability between some legal models circulating in Europe.

In the course of two centuries, these models totally eradicated the domestic law in Germany, replacing it with foreign law, only because it was foreign law.

Particularly, in Germany, the oldest work of legal literature in the Middle Ages had considerable influence on the process of circulation of foreign law. It was an accepted treatment of Saxon law, well-known with the name of "Sachsenspiegel”, compiled between 1224 and 1235. The Sachsenspiegel (Saxon mirror), written by Eike von Repgow, contains two parts (Landrecht e Lehenrecht). The work spread rapidly in all Germany and Europe in the XIIIth century, and translated into Latin became a vehicle for comparing German with foreign law, since the first glossator of Sachsenspiegel, Giovanni of Buck. In Germany, the reception of foreign law was developed by academic jurists in charge of the collection of laws and codes. At a later stage, in German universities, there was the recruiting of foreign professors and especially, after the Reformation, many Italian and French jurists looked for asylum in Germany.

In England, canonic law, applied in the ecclesiastical courts, significantly influenced the papers of Ranulf de Glanville (+1190) and, later, of Henry de Bracton (1216-1268). The works of Glanville and Bracton were more relevant to the development of law in England than Roman law (Pollock \& Maitland, 1898). Shortly after the first half of $X^{\text {th }}$ century, Sir John Fortescue (1394-1476) wrote between 1463 and 1471, the first comparative work, published posthumously in 1537-De laudibuslegum Angliae-in which he compared English and French law. Nevertheless, Fortescue-exiled in France, in Lorraine, with the Lancaster family after the battle of Towton in 1461-was Lord Chief Justice and, therefore, he well knew the institutions of his country when he compared English legal system with France and other countries subject to the civil law. During his exile, he studied these institutions (jurisdictional, political and legal) under the form of a dialogue between the prince and his chancellor. In the later centuries, this work exercised an extraordinary influence for distinguished students, like, for example, Montesquieu (Maitland, 1908). Fortescue, unlike Montesquieu, doesn’t have a historical vision, limiting himself to comparing only horizontally constitutional and legal institutions. If, on the one hand, emerges in Fortescue the lack of a longitudinal comparison-that "takes points of comparison also from legal history" (Husa, 2015) — on the other, it is evident the use of an apologetic comparison. In fact, Fortescue argued that the English Law was superior to the French.

In Spain, the hybridisation between Roman and German Law started with the publication of the Ley de SietePartidas of 1265, created by Alfonso X of Castile (1252-1284) to unify the different local laws, the fueros. The law of 1265, studied in the most ancient Spanish universities, came into force in 1348-with the promulgation of the Ordenamiento of Alcalá from Alfonso XI (1311-1350), and in Latin America until XIX ${ }^{\text {th }}$ century. The studies on National, canonic and Roman law-or even between the institutions that merged with the National laws, in France, Germany, England, Spain and Holland-were considered “only for internal comparison”. It happened because of a limited legal education of some scholars, but above all, because of the lack of perception of a clear idea of the own law, and that in order to distinguish it from ensuing works (Hug, 1932), defined as “external comparison”. Thanks to the work of the medieval Scholastics, Roman and canonic laws were prevalent 
in the European continent, thus excluding any requirement of comparative analysis. As much Roman law as canonical, we can consider it as a "true integration of national law" rather than foreign law.

In France, an important reform of legal education in the $\mathrm{XVI}^{\text {th }}$ century drafted by some French jurists of the Humanist School_Jacques Cuias (1522-1590), Françoise Hotman (1524-1590), Hugues Doneau (1527-1591) and Françoise Duaren (1509-1559)-laid the foundation for a systematisation of Roman law, which presupposed the combination of legal and historical studies. From this perspective, Roman law subjected to criticism the Justinian Roman law, to revalue the traditional Roman law (Van Caenegem, 1987). These jurists distinguished themselves not only for their critical studies of legal texts and a rich knowledge of sources, but also for a familiarity with literature and philosophy (Stevens, 1954). For example, Jacques Cujas studied the sources of law and the books of the most respected Glossators and, from 1544, he devoted himself to the study of wellknown jurists, specializing in the study of ancient languages, history, philology and moral philosophy. He was the professor in the most prestigious universities, such as Toulouse, Valencia and Turin.

Legal humanism took root in the regions of Europe in which there was a national law. It was sufficiently widespread to regulate the main legal questions, which had been open to legal interpretation. It primarily happened in France and Holland, whereas, in the rest of Europe, the Roman tradition continued to regulate wide areas of social life and, particularly, private law. According to Yntema, we can say that "[l]egal science and humanism have been inseparably joined in the historical development of modern culture” (Yntema, 1958).

\section{The Renaissance}

In the sixteenth century, in Europe, it was a legal studies movement that modified the tendency towards Roman law, with the abandonment of the interpretation based on the opinion Bartoli and the blossoming, especially in Germany and France, of schools of National jurists. They developed customary law by the scientific method, through a systematic comparison between domestic and Roman law (Hug, 1932).

In Germany, the usus modernus Pandectarum further increased the success of the Roman law, questioning its theoretical basis, as in, for example, the translation imperii. In substance, it was not accepted as a theoretical adoption of the Roman law, according to which the German emperors would not be the successors of Roman emperors; its reception was merely practical, insofar as the courts applied the Roman law. The consequences of this reception were essentially three. First was a renewed interest in national legal history; second, from a theoretical and practical point of view, much attention was paid to the domestic law of each country, which became an object of dogmatic construction; third, a greater adjustment of the education in law to the new national dimension. However, the usus modernus made it possible to explain differences between Roman and Saxon law. That was in evidence in the collections of Reinhard (1549-1551) and later those of Fachs, which were in new editions reviewed in the law faculties of Wittenberg and Leipzig. Moreover, Paulus Busius (1608-1614) in his Commentarius in Universas Pandectas Domini Justiniani studied the customs of the European countries and not only those of Germanic territories. At the previous stage, the enquiries into foreign law obscured the study of domestic law, as for the case of Germany, whereas, in the XVI ${ }^{\text {th }}$ century Roman law, legal scholars made it compatible with new common law of the kingdoms. This trend was beginning to emerge in the great monarchies of Southern and Western Europe and the Italian states.

In England, a series of factors contributed to enabling jurists to make comparisons. The characteristics of its common law arose by contact with foreign law; very soon, the Anglo-Saxon jurists perceived differences between their system and Roman and canonical law. Nevertheless, political reasons caused English jurists to be suspicious of foreign law, defending status quo. There was a firm conviction that the spirit of English common law was incompatible with the theory of the civil or Roman law, which prevailed in other countries. There was another negative perspective for comparison, visible in some cases of declamatory comparison: the English scholars used the comparison with foreign law mainly to contrast it. In any case, until the Roman law had influence in England, there was a little room for comparison. The embryonic character of the comparative approach was also discovered in the book The Governance of England, where comparison only presented an apologetic nature. In 1523, Christopher Saint-Germain (1460-1540) edited the book Doctor and Student (1523), the most important treatise in a comparative perspective on the relationship between Common and canonical law until Blackstone's Commentaries. In spite of critics of historical and methodological views, Saint-Germain demonstrated an understanding of comparative systems (Hug, 1932), and gave importance to Equity in the Tudor Age. In $\mathrm{XVI}^{\text {th }}$ century, Henry VIII of England instituted Chairs of Roman law in Oxford and Cambridge to allow 
English diplomats to better negotiate with the ambassadors coming from the area of continental law. However, there were few publications of comparative law in $\mathrm{XVI}^{\text {th }}$ century; the use of comparison was negligible, restricted to existing territorial areas. At the beginning, of XVII ${ }^{\text {th }}$ century, there was a marked change in the history of comparative law, thanks to the works of William Full beck (1560-1603?), who compared common law with canonical and civil law, without yet being able to present the comparison between different legal systems with a scientific methodology. On the same wavelength, John Cowell (1554-1611) made a comparison between Roman law and the English legal system, taking as his basis the language of the Institutes of Justinian. In Scotland, Sir James Dalrympe, 1st Viscount of Stair (1619-1695) edited a book in which he compared Scottish with the civil, canonical, feudal and customary law of other countries. Until the end of the XVII ${ }^{\text {th }}$ century, the study of foreign law had as its main purpose preventing its circulation, but that was possible because the English scholars studied the law and comparison from an empirical point of view.

In France, customary law spread at the beginning of the XVI ${ }^{\text {th }}$ century and legal comparison had concerns especially in unwritten Roman and German customary law. This evolution provoked the end of Bartolism, as it happened in Germany where there was a fragmentation of French law. To the North of the Loire, the customs of German origin were predominant, whereas, in the South, Roman law was more prominent. This was important: the local French-German law diminished this dualism. It did not originate in opposition, but in connection with the Roman law, from which essential concepts derived. The official compilation of the coutumes, impelled by Charles VII with the decree of Monils-les-Tours in 1454, eliminated many local customs, introducing general customs.

During the $\mathrm{XVI}^{\text {th }}$ and $\mathrm{XVII}^{\text {th }}$ centuries, a French jurists, Charles Dumoulin (1500-1566), created the droit civil commun, extracting the common parts of each one of the customs and commenting on them. The contribution of the coutume of Paris, codified in 1510 and reformed in 1580, was so influencial, that it became the most important source of law between the cours souveraines and the jurisprudence of the parliament of Paris. In the XVI ${ }^{\text {th }}$ century, a comparative point of view appeared in the criticism of scholastic jurisprudence. We can point out the contribution of Jean Bodin (1529-1596), who promoted the construction of Roman law within a historical context dispersing the schemes of the School of Glossators, through comparison. A confrontation between the Roman institutions and others contributed "to the construction of a universal comparative constitutional law", creating the bases for comparison between ancient and modern institutes (Franklin, 1977).

In Italy, the $\mathrm{XVI}^{\text {th }}$ century restored the influence of Roman law through the historic and critical study of the sources of law, to which Andrea Alciato (1492-1550), the most famous jurist during the Renaissance, gave a remarkable impetus. Considered the founder of traditional methodology in the Italian schools (the mositalicus or mosgallicus during the $\mathrm{XVI}^{\text {th }}$ century in France), Alciatoanalised, in several works, the main interpretative questions of Justinian's texts (Paradoxa, Parerga, Emblemata). After studying in Pavia and Bologna, he moved to France, teaching in Avignon and Bruges from 1518 to 1533 and then he continued this activity in Italy (Pavia, Bologna, Ferrara).

In Spain, in the $\mathrm{XVI}^{\text {th }}$ century, works of comparison between Roman and indigenous law were edited, especially after the discovery of the New World. Amongst the most notable works, we would recommend those of Juan Bautista Villalobos, Antinomia iuris regni Hispaniarum et civilis (Salamanca, 1569), Martín de Olano, Concordia et nova reduction antinomiarum iuris communis et Regni Hispaniarum (Burgos, 1575), SebastiánXiménez, Concordia seu concordiantie utriusque iuris civilis et canonici (Toledo, 1596), Gregorio García, Origen de losindios de el nuevomundo e Indias Occidentales (1604). These writers compared traditions and customs of peoples whom the Spanish found in their colonies with Spanish and Hebrew law (Hug, 1932). In all these works, we can point out the analysis of foreign experience through the use of comparative methodology, although not systematically. In all of these forms of comparison, and particularly from a historical and methodological points of view, legal scholars introduced something new for comparative enquiries. In Holland, Hugo Grotius (1583-1645), whose knowledge was encyclopedic (Hug, 1932), used materials coming from many countries and of different times, with the aim of demonstrating the universal validity of natural law. From this point of view, he was convinced that all rules or institutions found acceptance in other legal systems. Even so, the use of these materials was not dissimilar to that happened in the Middle Ages, but it is not a legal comparison in the modern sense.

\section{The Seventeenth and Eighteenth Centuries}

At this stage, a great development of comparative methodology took place, mainly in England, just as in France, 
Germany and later in Switzerland by way of the elaboration of common law from the jurists of the time. Continental lawyers, but also common law scholars, frequently used comparison in XVII ${ }^{\text {th }}$ and XVIII ${ }^{\text {th }}$ centuries, in order to look for agreements between the law of different regions or countries and to determine the communis opinio or praxis totiusorbis (totius Europae), that had a remarkable role for the solutions that refer to case law.

Thanks to the development of the press and circulation of legal books, in England, lawyers had more opportunities to direct to study the laws of other countries. Amongst the first comparative books, we could refer to the dialogue of William Fulbeck (1560-1603?), who illustrated, in the form of descriptive dialogue, Common, Roman and Canonic law without still using a comparative methodology. Although the success of the later works was considerable, in this period, the predominance of the School of Natural Law and its methodology prevented a development of comparative studies. This negative attitude toward use of foreign law does cannot be found in Francis Bacon (1561-1626), a connoisseur of law and with a strong, idealistic, tendency (Hug, 1932), who proposed in his De dignitate et augmentis scientiarum (1623) a model of universal justice. Also Leibniz (16461716), who returned to study this subject after almost forty years, editing the work Nova methodus discendae docendaeque iurisprudentiae (1667), in which, among other things, he hoped for a new direction for legal studies in a historic and comparative context.

King James I requested the advice of Bacon, who formulated the compelling proposal directed to the jurists of both countries with the purpose of unifying English and Scottish law, after the approval of the Act of Union. Nevertheless, the aim of formulating the laws of each country in two parallel columns to carry out a comparison, analysing above all differences. Another English scholar, John Selden (1584-1654), was particularly interested in foreign law. Unlike Bacon, Selden was a connoisseur of the history of law of which he was a prominent and well considered expert (Hazeltine, 1910). In particular, he addressed his studies to shed light on the influence of Roman law on the English law, as in the books De diis Syriis (1617), De successionibus in bona defunctorum ad leges ebraeorum (1631) or De iure naturali et gentium iuxta disciplinam Ebraeorum (1640). He distinguished himself in a comparative approach, such as in the History of Tithes and Titles of Honour (1618), DissertatioadFletam (1647)—in which he gave particular attention to the Eastern countries and Hebrew law-and Table Talk (1689), after his death. The works of Selden marked the beginning of the "comparative history of law" (Hug, 1932). In 1693, J. Dalrymple, $1^{\text {st }}$ Viscount of Stair (1619-1695), published a book containing a comparative analysis, Institutions of the Law of Scotland, collated with the Civil, Canon and Feudal Laws and the Customs of Neighboring Nations. He had a deep knowledge of Roman and French Law and this knowledge allowed him, on the one hand, to establish the basis of English mercantile law. On the other hand, he studied foreign solutions that might lead to a more liberal and advanced system of Common Law in England. Lord Mansfield supported the appointment of William Blackstone (1723-1780), the writer of the Commentaries on the Laws of England, edited between 1765 and 1769, for the Vinerian Chair in Oxford, in 1758. The first American edition of the Commentaries, printed in the period 1771-1772, was hugely popular; thousands of lawyers on both sides of the Atlantic believed in the ideas set out in the Commentaries (Gilmore, 1977). Inspired by Blackstone, Sir William Jones (1746-1794), the connoisseur of the comparative method and who spoke 28 languages wrote significant works, such as an Essay on the Law of Bailments (1781), Institutes of Hindu Law (1784), Muhammedan Law of Inheritance (1786). In France, comparison mainly moved towards the internal approach to explaining the basic principles of French common law, as in the works of Robert-Joseph Pothier (1699-1722). Nevertheless, Charles de Secondat, baron of Montesquieu (1689-1755) was the first to change the comparative point of view from an external perspective. L'Esprit des Lois, edited in Geneva in 1748, and later translated and re-edited on several occasions, exerted a considerable influence in Europe and the United States. This book was “undisputedly, a-if not the-defining moment in the history of comparative law” (Hirschl, 2009). Montesquieu was one of the founders of political science and also a connoisseur of constitutional law and the existing relationship between the two disciplines. As much in L'Esprit des Lois, as in the Lettres Persanes, Montesquieu used comparison unlike his predecessors, as a source of legislative and legal action. We could point out that one of his central ideas was the belief that some factors like history, policy, religion and climate influenced the laws of each different country. According to this sociological and comparative approach, a knowledge of the culture of a country should not be confused with the content of its laws. Incidentally, Constantinesco argued: "To understand the norms is to identify the causes which have determined these norms; in other words, the knowledge of foreign law requires the insertion of the text in the organ that constitutes it, examining it within the scope of the system and with respect to the factors that influence it” (Constantinesco, 1972). In particular, Chapter IV of Book XI of Montesquieu's Esprit de Lois, “De la Constitution d'Angleterre”, the reflections on England expressed in the 
Rousseau's Contrat Social and the Constitution de l'Angleterre by J.L. de Lolme of 1771 showed that it was necessary for continental lawyers to compare themselves with English institutions. From a comparative point of view, they pointed out that it was necessary to look for English models to imitate, or examples to reflect on the domestic reforms.

In Italy, Giovanni Battista Vico (1668-1744) contributed to the strengthening of returning to historical awareness. For Vico, "universal” was not abstract, but it was a positive notion, produced by the history of humanity. In his legal studies, he directed himself to the pursuit of universal legal principles. Vico maintained that natural law developed in parallel and separate from the legal history of the countries. According to him, "a regular correlation between human thought and social facts [...] and a palpable connection between natural law and identified legal principles with the aid of the comparison, between different, positive, laws” exists (Constantinesco, 1972).

Although the theory of Vico could represent an obstacle to a legal comparison, according to the rationalist tendency of the studies of the end of XVIII ${ }^{\text {th }}$ century, comparative analysis of the different constitutional experiences remained between the study perspectives. This trend was evident in the first treatise of constitutional law, edited by Giuseppe Compagnoni (1754-1833), titled Elementi di diritto costituzionale cispadano e pubblicistico universale. In this book, he collected the lectures made at the University of Ferrara in 1797, as Professor of the first Chair of Constitutional Law in Europe. The course had its beginning with the inaugural lecture of 2nd of May of 1797 which represented a clear sign of the consolidation of the new central government of the Cispadane Republic. However, Compagnoni assumed the chair until November of the same year, when he joined the assembly of the Great Council of the Cisalpine Republic. The institution of the Chair of Constitutional Law brought about the suppression of those of Roman, canonical law and the profession of notary. We must point out that the Austrians closed the University of Ferrara on the $23^{\text {rd }}$ May 1799, but there were other Chairs of Constitutional Law in Pavia and Bologna. The remarkable book of Compagnoni demonstrated not only the Jacobin and Republican proposal, but also the new principles of constitutional law, following the Compagnoni's philosophy.

In the United States, the interest in foreign law was clear in the XVIII ${ }^{\text {th }}$ century by the political contrast between French and English law. If, on the one hand, American judges and scholars used William Blackstone's Commentaries on the Laws of England (Friedman, 1973), on the other hand, after the French Revolution, the liberal North Americans were themselves attracted by French civil law. The French jurists inspired Thomas Jefferson, father of the Declaration of Independence of 1776. Despite this, one of the main problems that emerged was the limited knowledge of French, unlike the English, which represented the common element between English and North American scholars. Joseph Storm member of the Supreme Court, and James Kent, two prestigious American scholars, precursors of comparative law, contributed to the development of English law in the United States.

\section{The Nineteenth Century}

The XIX ${ }^{\text {th }}$ century represented the departure point for progress in the modern sense of comparative law (Hug, 1932), with the emergence of a scientific curiosity towards disciplines in which comparison represented a fruitful methodology (linguistic, anatomical). This phenomenon imposed on the national jurists a knowledge of the foreign law. Under the influence of the historical School of the law, founded by Savigny (1779-1861), many scholars debated on the use of comparison. If, on the one hand, some scholars maintained that the national character of law could limit the interest for comparative enquiries, the predominant opinion was that the Historical School contributed to the development of comparative analysis.

During the first half of the XIX ${ }^{\text {th }}$ century, some students of this School promoted comparative methodology and gave a memorable impulse to the doctrine of comparative legislations. In the XIX ${ }^{\text {th }}$ century, the interest and education in the legal comparison gave birth to the emergence of centers within universities in different countries that had as their purpose "a comparative spirit", necessary for analyzing domestic law. In Germany, P.J. Anselm Ritter von Feuerbach (1775-1833), the most famous professor of penal law of his times and philosopher of law followed the Kantian movement of critical rationalism and formulated the theory of a universal science of comparative law. He was also one of first in criticizing the "parochialism" of the German students. The contribution of Eduard Gans (1798-1839) was in opposition to the Historical School and favour of a philosophical interpretation of the history of law, considering that the history of law of each country contributes to a universal law of nature. 
The publication only of some chapters of his work on the universal science of law, like, for example, those on China, Siberia, India, and America demonstrated the absence during that period of a sufficient knowledge of legal materials and foreign languages. If Feuerbach and Gans represented the philosophical current of comparative legal studies, Karl S. Zachariae (1769-1843) and Carl Mittermaier (1787-1867) directed these studies towards a practical perspective of comparison, analyzing the elements coming from the French, English and American legal systems. They founded in 1829 the review Kritische Zeitschriftfür Rechtswissenschaft a Gesetzgebung des Ausländes, that, from 1829 to 1856, promoted papers on the legislation and the legal science of foreign countries. In other words, this review was the first to leave the ordinary perspective of national law (Constantinesco, 1972).

In France, the interest in foreign legislation had a new boost in XIX ${ }^{\text {th }}$ century: Napoleon Bonaparte created, in 1801, acenter on foreign legislation to classify, translate and study the most important laws of the foreign countries. Nevertheless, after the translation of the general code of the Prussian States, the center no longer existed. In 1831, at the School of France in Paris, there was the establishment of a Chair of Comparative Law, with a historical and philosophical character, assigned to Eugène Lerminier (1803-1857). Moreover, we can point out that, in 1834, Jean Jacques Gaspard Foelix, advocate for the use of comparative methodology, founded the Revue Étrangère de Législation; and then Edouard Lambert (1866-1947) and Raymond Saleilles (1865-1912) gave their essential contribution to developing the practical functions of comparison. In particular, Saleilles showed how legal comparison developed through two distinct interconnected phases. In the first, the searcher puts in evidence common elements of each legislation through analysis of legal systems and institutes. In the second, the comparatist presents the results of his analysis for a later application by lawmakers or foreign scholars. It is worth pointing out the $16^{\text {th }}$ February 1869 saw the opening in Paris of Société de la Legislation Compareé, with some "rooms" dedicated to legal systems of French and German systems, but with a remarkable preference for English law.

In England, comparative law had a slower development with respect to other countries: the legacy of the jurist Charles Viner (1678-1756) was necessary for the creation of a Chair of English Law at the University of Oxford and the establishment of this subject in the official curriculum. The first holder of this Chair was Sir William Blackstone, whose classes were based on the Commentaries on the Laws of England (1765-1769). After Blackstone, the Chair gradually lost prestige, since their occupants had considered it as a sinecure. In the nineteenth century, unlike the German universities in which the legal faculties had acquired considerable fame, in England the idea of a serious legal education was open to debate. It was not accidental that Albert Venn Dicey (18351922), Professor of the Vinerian chair in Oxford made the opening speech for the course in 1882: "Is it possible to give lectures on English law at the University?” In England, the course of Scottish law implied the corresponding education in Roman and English law that, together, formed the basis of university studies. In 1861, Sir Henry Maine (1822-1888) published the famous work Ancient Law and in 1869 he had the Chair of Historical and Comparative Jurisprudence, contributing to the advance of comparative law in Great Britain (Gutteridge, 1949). Another factor to consider for the opening of new Chairs in comparison was private donations. In 1894, following a legacy of Sir Richard Quain, a judge in the Queen's Bench Division, a Chair in Comparative Law at the University College of London was created. In 1869, the Society of Comparative Legislation was founded in London to promote comparative inquiries, methodology and a collection of normative materials mainly of English and North American law. In Spain, amongst the precursors of comparison in the field of constitutional law, we would remember Adolfo Posada, Professor at Oviedo University, who wrote the famous Derecho político, which was not only a treatise on constitutional law but also a book of comparative constitutional law, with interesting observations about legal education. Finally, we cannot ignore Gumersindo de Azcárate (1840-1917), who held the Chair of Comparative Legislation at the University of Madrid from 1873 to 1915 and gave a remarkable contribution to the Spanish legislation of the XIX ${ }^{\text {th }}$ century. In other countries towards the end of century XIX ${ }^{\text {th }}$ century, also in Spain, a comparative journal was founded, the Revista de Derecho Internacional y de Legislación comparada.

In Italy, the father of comparative law was Emerico Amari (1810-1870), who expressed a philosophical theory of comparative law. In the famous Critica di una scienza delle legislazioni comparate, he pointed out the need of studying laws of different countries and times for the creation of an independent science of legislation, inspired by the principles of natural law, and the theory of Vico. Moreover, we could bring into consideration the contribution of C.F. Gabba (1835-1920), above all for the use of comparative legislation in the formation of national sources of law. 
In the United States, at the beginning of the XIX ${ }^{\text {th }}$ century, a feeling of deep opposition with respect to the mother country spread, up to point at which some laws prohibited the use of English legal materials for judgments in the courts. For example, the law of New Jersey of 1799 (countermanded in 1819) not only prohibited the installation of later English judgements following 1776, but also "any collection, commentary, lecture, reading, treatise or another report or expression of the common law" (Friedman, 1973). From this point of view, also J.W. Burgess (1844-1931), one of the fathers of political science, edited in 1891 the book Political Science and Comparative Constitutional Law, containing general subjects for comparison in constitutional law, as the forms of government.

\section{From the Congress in Paris, 1900, to the First Half of the Twentieth Century}

The International Congress of Comparative Law celebrated in Paris, on the occasion of the Universal Exhibition of 1900, marked the beginning of comparative law in a modern sense. Sir Frederick Pollock (1845-1937) and Joseph Kohler (1849-1919) were only some of the most influential jurists who participated in the Congress. The organisers of the Congress, Raymond Saleilles (1855-1912), his followers Edouard Lambert (1849-1941) and Henry Lévy-Ullmann (1870-1947), who are considered the precursors of the French Academy of Comparative Law pursued two objectives: to approach common problems of different legal disciplines; and to define functions, objectives and methodology. Professor Lambert's lecture on the general theory and methodology of comparative law represented the starting point of a new and autonomous science and clarified the essential functions of comparative law. According to their "realistic" theory, Saleilles, Lambert and Lévy-Ulmann pointed out that comparison is a mechanism to improve the law. Following the Congress in Paris, comparative law increased in importance some countries, mainly after the end of the First World War, with the birth of research centres and university Chairs in Comparative Law. In France, at the beginning of the 1900s we can identify a Chair of History of Comparative Law at the Collège de France-whose first holder was E. Lerminier-and ten Chairs of Advanced and Comparative Civil Law. Nevertheless, the courses were not homogenous, and comparison was only a means to develop French law: according to Lambert, only private law could be considered as an object for comparison. In 1920, Lambert founded in Lyons the Institut de Droit Comparé, directed by Lévy-Ullmann during 1929 and 1930, that became a model for other universities, for the study of foreign law and the development of comparative methodology. In 1924, Jacques Maury founded the Institut de Droit comparé des Pays Latins, at the University of Toulouse, which published studies about Spanish law; in 1931, Lévy-Ullmann with Henri Capitant (1865-1937) founded, in Paris, the Institut de Droit comparé, at the Faculty of law. Moreover, in 1944, Barthélemy (1874-1975) published the Course of comparative constitutional law.

In Germany, in 1900 the civil code (BGB) came into force and absorbed the interest of the German jurists for some decades. They were not seriously interested in comparative law, preferring other disciplines like legal ethnology, comparative history and philosophy of law. On the contrary, Ernst Rabel (1874-1955), a follower of Ludwig Mitteis (1859-1921) in Leipzig, obtained in 1902 a qualification in History of law; he made an essential contribution to comparative science. After he was awarded the Chair at the University of Munich, where the first institute of comparative law in Germany was founded in 1917-the Kaiser Wilhelm Gesellschaft, other institutes were founded in Berlin (1926), Heidelberg, Hamburg and Breslavia. Rabel was editor-in-chief of the prestigious journal Zeitschrift für auslandisches und internationals privat-und offentliches recht; he produced distinguished works of comparative law and influenced European and American jurists in the second half of the twentieth century. The contribution of this master of comparative law was essential for comparative methodology.

As Rheinstein argued, according to Rabel, legal rules and concepts could be applied by judges to legal phenomena in all legislative systems between which conflicts would have to be resolved (Rheinstein, 1956), applying comparative law to judicial praxis. In view of Markesinis, many professors followed Rabel's theory, reinforcing the field of comparative law. Nevertheless, in Germany, comparative history, philosophy of law and legal ethnology were more widespread than comparative law (Markesinis, 2003).

In Great Britain, comparative studies were not so advanced than in other European countries. Nevertheless, the Society of Comparative Legislation published its Journal from 1896. Despite the creation, in 1945, of a Chair of Comparative Law in Cambridge, for Sir Arnold McNair (1885-1975), these studies did not develop, in spite of the presence of eminent scholars like Sir J. Mac Donell (1846-1921), Sir M.S. Masters (1872-1940) and R.W. Lee (1868-1958). Even in 1938, Lee argued that there were not similar institutes of comparative law to those existing in continental Europe. The most important were in London-under the direction of Gutteridge 
and later of Masters_-Cambridge and Manchester.

In the United States, the process of development of comparative law was remarkably similar to Great Britain. There were not many institutes in the Universities - except Harvard, Yale, Columbia, and Chicago-and furthermore the publishing of books of comparative law "was not so good” (Constantinesco, 1972). However, the foundation of some legal journals like the Harvard Law Review (1887), the Yale Law Journal (1891), the North-Western Law Review (1906) and the Tulane Law Review (1916) contributed to the growth of comparative science. The most brilliant comparative jurists during this period were J.H. Wigmore (1863-1943) and R. Pound (1870-1964).

In Italy, the exponents of the historical-philosophical school played a leading role in founding comparative law as an autonomous legal science. Especially Giorgio del Vecchio (1878-1970) considered comparative law as a universal history of law. Furthermore, through grouping the legal systems in a certain category, it was possible to interpret the same systems as elements of a universal and historical process. In this context, Evaristo Carusi (1866-1940), an exponent of the historical current and Professor of Muslim Law, in 1917, published an essay on comparative law in which he tackled the relationship between comparative science and linguistics. After the First World War, legal centres for the study of comparative law were founded. In 1927, in Rome, Galgano founded the Istituto di studi legislativi; in 1924, in Milan, Rotondi created the Istituto di diritto commerciale comparato, famous in many countries for the translation of his essay Dogmatica e diritto comparato of 1926. During the fascist period, the publication of comparative law books was restricted to introductory or practical works, like those of M. Sarfatti on comparative public law in 1933, A. Ravà in 1934, L. Rossi in 1935, R. Monaco and G.L. Capobianco in 1936, of G. Fontana in 1938 and Amorth in 1947. In the same year, Rodolfo Sacco, the most famous Italian comparative scholar and professor at the University of Turin, published his first book on the interpretation of the law.

In Spain, after the elemental treatise of T. Elorrieta and Artaza (1916), in 1944, the handbook of comparative constitutional law by L. del Valle Pascual was published in 1944.

\section{The Second half of the Twentieth Century}

After the Second World War, there was a remarkable interest in comparative law, particularly in private and public (constitutional and administrative) law. The adoption of new Constitutions in Europe (Germany, Italy) and the development of the external relationship, like, for example, the United States and Russia, contributed to revitalise comparative science. Intense scientific production, congresses dedicated to the methodology and the creation of research institutes and new legal journals were evidence of this trend (Reimann, 2002). In the fifties, and at the beginning of the sixties, some indicators pointed to comparative law having a significant development in the countries of Western legal tradition. I would particularly point out the comparative works published during this period: In 1950, the casebook of R. Schlesinger and the treatise of R. David, works of F. Lawson (1953), G. Gorla (1954) and A. von Mehren (1957), handbooks of comparative constitutional (and public) law. In Italy, we could note those of R. Sandiford (1951), C. Mortati (1958); in Spain, M. GarcíaPelayo (1950), F. de Sola Cañizares (1954) and L. Sánchez Agesta (1963); in France, P. Bastid (1957). In the fifties, the establishment of prestigious reviews gave an essential contribution to legal theories and comparative methodology: The Revue internationale de droit comparé, founded in 1949, and the American Journal of Comparative Law (AJCL), founded by H. Yntema in 1952 at the University of Michigan, were the most prestigious journals of comparative law. Apropos of the American Journal, it can be seen that, in the first volume, there were articles of constitutional law (by A.T von Mehren) and comparative methodology (by E.D. Re). In the same year 1952, in London, another review was published, The International and Comparative Law Quarterly. Also in Latin America, the BoletinMexicano de Derechocomparado has contributed to the growth of comparative law since 1948.

Nevertheless, we could also note some negative reactions after the Second World War, particularly about political phenomena like the Cold War or the dictatorships, in fact, they prevented the circulation of foreign legal models, for example, concerning the fundamental rights or the forms of government. Additionally, concerning comparative law, I can mention, for example, that the University of Suchow, founded in Shanghai, in 1900, already had some programs in comparative law, with the participation of English and American professors, already from 1915. The University closed in 1952, following the three years of the rise to power of Mao Tse-tung in 1949. This example could be useful to demonstrate that the interest in comparison can be seen to diminish because of social, political or normative factors (like a blundering mismanaged reform of university), as also 
happens with submergence (or the revival) of "crypto types". In the second part of the fifties, according to Reimann, we could consider comparative law as a "body of knowledge". This idea implied not only the use of the methodology, but also the introduction of courses of comparative law, publication of famous books, but especially a new map of traditions and legal cultures, inspired by dynamic models of legal families (Reimann, 2002).

After the Second World War, there was a process of "Americanisation of law", initially in Western Europe and later also in the areas of socialist law coinciding with a progressive spread of English in many countries, like a second language in scholastic centres. The diffusion of English has had in former times the political, economic and educational contributions of American and British governmental and private organizations.

Two other important masters in comparative law of the twentieth century are Rudolf B. Schlesinger and Rodolfo Sacco. What was their inheritance? The fame of Schlesinger is legendary and, particularly, his case method (or factual approach) that was known throughout the world thanks to his own Case Book, the first of comparative law in history. This methodology applied at Cornell in the early sixties, in the Common Core Project, "has been a turning point not only in comparative law methodology, but also in comparative anthropology (Mattei, 2011). Also Rodolfo Sacco's theory of “legal formants” opens up many fields of analysis (Sacco, 1991). Many scholars, both in private and in public law, follow his comparative method.

In the new $21^{\text {st }}$ century, some important comparative works are destined to reinforce the science of comparative law anywhere in the world, extending the legal comparison to other cultures and traditions-like, for example, China, India, Japan, or Africa — and, consequently, the geographic course of comparative investigations. Therefore, the choice of these perspectives has implications for significant comparative legal studies and a new generation of legal scholars.

\section{Conclusions}

This Essay offers a short reconstruction of the historical evolution of legal comparison. As Husa notes, "[t]he history of comparative law is not an autonomous history of an independent scholarly field of law as a discipline but part of the general history of legal ideas. The origins of scientific comparative study are in the research of societies and people deep in the Western tradition of science" (Husa, 2015). Of course, legal history does not represent the principal aim of comparative enquiry, but the eye of a comparatist looks at a historical fact, beyond legal classification, with freedom, without prejudice, and whether it is a matter of autochthonous law, as of foreign law. The parallel evolution of the law and culture, i.e. in the schools for philosophers, has favored birth and development of legal and comparative political studies from ancient times until today. From Late Antiquity, the spread of ideas, customs, as well as the legal texts, from one society to anotherwas made through travel. All in all, legal comparison is a travel and the comparatist is a traveler, "He travels only to return. He then travels to tell. He travels to understand himself and others" (Lupoi, 2001). In this way, the models contained in the legal codes, such as the Collatiolegum Romanorum et Mosaicarum, the Twelve Tables of Rome or the Laws of Manu spread, both for prestige and for authorities.

The legacy of the Middle Ages was important for the development of the common ius commune. Husa has captured this moment in the following words: "[i]n the Middle Ages it was typical in legal decision-making to cross national borders when the rule that would probably solve the case was looked for. It is important to notice that at that time jurists studied the legal source material and authorities in order to find from the common ius commune tradition a legal rule the same as in their own legal system, not in order to obtain from foreign law inspiration for their own decision-making” (Husa, 2015).

Legal humanism took root in the regions of Europe in which there was a national law. It was sufficiently widespread to regulate the main legal questions, which had been open to legal interpretation. It primarily happened in France and Holland, whereas, in the rest of Europe, the Roman tradition continued to regulate wide areas of social life and, particularly, private law. According to Yntema, we can say that "[l]egal science and humanism have been inseparably joined in the historical development of modern culture" (Yntema, 1958).

Between the seventeenth and eighteenth centuries, a great development of comparative methodology took place, mainly in England, just as in France, Germany and later in Switzerland by way of the elaboration of common law from the jurists of the time. Continental lawyers, but also common law scholars, frequently used comparison in XVII ${ }^{\text {th }}$ and XVIII ${ }^{\text {th }}$ centuries, in order to look for agreements between the law of different regions or countries and to determine the communis opinio or praxis totius orbis (totius Europae), that had a remarkable role for the solutions that refer to case law. 
After this period, we must remember the important lesson of Montesquieu for the development of comparative law: he was the first master of modern comparative law. According to Hirschl, it is necessary to say that Montesquieu's "Spirit of Laws" was "undisputedly, a —if not the-defining moment in the history of comparative law". Montesquieu's foundational approach of unearthing linksbetween law and societies across cultures has inspired an impressive tradition of comparative scholarship" (Hirschl, 2009). Montesquieu considers the inclusion of Asia within a broad comparative perspective and the impact of factors such as climate, geography, history, religion and custom on one or another form of government. According to Montesquieu, these factors affected "republic ad monarchies" in Europe and "despotisms rule" in the rest of the world" (Launay, 2001). Although this position is not acceptable today, the merit of the French scholar was also to have initiated a debate on the methodological pluralism in comparative law (Zucca, 2009; Scarciglia, 2015). The importance of this debate is also visible in the nineteenth century, that represented the departure point for progress in the modern sense of comparative law (Hug, 1932), with the emergence of scientific curiosity towards disciplines in which comparison represented a fruitful methodology. This phenomenon imposed on the national jurists a knowledge of the foreign law. The International Congress of Comparative Law celebrated in Paris, on the occasion of the Universal Exhibition of 1900, marked the beginning of comparative law in a modern sense. According to Riles, "[i]n the twentieth century, however, all this is understood to have changed. Comparative law became more "scientific" and abandoned its evolutionary framework in favour of a more functionalist understanding of law" (Riles, 1999). Tomark the transition between the ninth and the twentieth century was Henry Wig more. From a counterintuitive point of view, he "seems consciously to ignore conventional scholarly methods and norms that made work analytically significant" (Riles, 1999). His kaleidoscope has enabled many scholars to realize the importance of transnational markets and rules, immigration patterns and cultural environments. Another key figure was Ernst Rabel. He influenced European and American jurists in the second half of the twentieth century. The contribution of this master of law was essential for comparative methodology and many professors followed Rabel's theory, reinforcing the field of comparative law. In this respect, "[h]is so called function/context method has dominated much of the work done in comparative law since the Second World War" (Gerber, 2001). After the Second World War, we pointed out the remarkable interest in comparative law, particularly in private and public law. The adoption of new Constitutions in Europe and the development of the external relationships contributed to revitalise comparative science. After Edouard Lambert and Harold Gutteridge, without doubt, one of the best-known figures in this period was René David, father of the division of the world's legal systems into family groups, also if "this notion of legal families is not reducible to the mere commonplace that national legal systems share common elements across the countries" (Esquirol, 2001).

Two other important masters in comparative law of the twentieth century are Rudolf B. Schlesinger and Rodolfo Sacco. What was their inheritance? The fame of Schlesinger is legendary and, particularly, his case method (or factual approach) that was known throughout the world thanks to his own Case Book, the first of comparative law in history. This methodology applied at Cornell in the early sixties, in the Common Core Project, "has been a turning point not only in comparative law methodology, but also in comparative anthropology (Mattei, 2011). Also Rodolfo Sacco's theory of “legal formants” opens up many fields of analysis (Sacco, 1991). Many scholars, both in private and in public law, follow his comparative method. In the new $21^{\text {st }}$ century, some important comparative works are destined to reinforce the science of comparative law anywhere in the world, extending the legal comparison to other cultures and traditions-like, for example, China, India, Japan, or Africa - and, consequently, the geographic course of comparative investigations. From this point of view, comparative law is enriched by interdisciplinary essays- "from Comparison to Collaboration", according to Riles (Riles, 2014) - that includes anthropology, philosophy or cognitive sciences. Therefore, the choice of these perspectives has implications for significant comparative legal studies and a new generation of legal scholars. We have to say thanks to the masters of the past for their lesson.

(A Critique of a Science of Comparative Legislation)

\section{References}

Amari, E. (1857). Critica di una scienza delle legislazioni comparate (A Critiqueof a Science of Comparative Legislation), Vol. I-II. Genoa: R.I. de’ Sordomuti, repr. (1969). Palermo: Edizioni della Regione siciliana, 139.

Bognetti, G. (1994). Introduzione al diritto costituzionale comparato. Il metodo (p. 26). (Introduction to Comparative Constitutional Law: The Method). Turin: Giappichelli.

Constantinesco, L. J. (1972). Die rechtsvergleichende Methode (p. 82). (Comparative Law: Comparative Method). Köln: 
Karl Heymanns.

Croce, B. (1943). Teoria e storia della storiografia (5th ed., p. 12). (Theory and History of Historiography). Bari: Laterza.

Esmein, A. (1899). Éléments de droit constitutionnel français et comparé (Elements of Frenchand Comparative Constitutional Law), repr. (2001). Paris: Éditions Panthéon-Assas.

Esquirol, J. L. (2001). René David: At the Head of the Legal Family. In A. Riles, Ed., Rethinking the Masters of Comparative Law (p. 234). Oxford and Portland OR: Hart.

Franklin, J. H. (1977). Jean Bodin and the Sixtenth-Century Revolution in the Methodology of Law and History (2nd ed., p. 116). New York: Columbia University Press.

Friedman, L. H. (1973). History of American Law (p. 98). New York: Simon \& Schuster. http://dx.doi.org/10.2307/845101

Gerber, D. J. (2001). Sculpting the Agenda of Comparative Law: Ernst Rabel and the Façade of Language. In A. Riles (Ed.), Rethinking the Masters of Comparative Law (p. 190). Oxford and Portland OR: Hart.

Gilmore, G. (1977). The Ages of American Law (p. 10). New Haven and London: Yale University Press.

Gorla, G. (1964). Diritto comparato [Comparative Law]. In Enciclopedia del Diritto [Encyclopedia of Law] (Vol. XII, p. 930, nt. 5). Milan: Giuffrè.

Gutteridge, H. C. (1949). Comparative Law. An Introduction to the Comparative Method of Legal Study and Research. Cambridge: Cambridge University Press.

Hazeltine, H. D. (1910). Selden as Legal Historian. Harvard Law Review, 24, 105-118. http://dx.doi.org/10.2307/1324818

Hirschl, R. (2009). Montesquieu and the Renaissance of Comparative Constitutional Law. In R. E. Kingston (Ed.), Montesquieu and His Legacy (pp. 199-220). Albany, NY: State University of New York Press.

Hug, W. (1932). The History of Comparative Law. Harvard Law Review, 45, 1027-1070. http://dx.doi.org/10.2307/1332143

Husa, J. (2015). A New Introduction to Comparative Law (p. 104). Oxford and Portland, OR: Hart.

Launay, R. (2001). Montesquieu: The Specter of Despotism and the Origins of Comparative Law. In A. Riles (Ed.), Rethinking the Masters of Comparative Law (pp. 22-38). Oxford and Portland, OR: Hart.

Le Goff, J. (1979). Les intellectuels au Moyen Age [Intellectuals in the Middle Ages] (p. 70). Paris: Seuil.

Lupoi, M. (2001). Sistemi giuridici comparati. Traccia per un corso [Comparative Legal Systems: Course Tracks] (p. 15). Rome: Istituto Poligraficodello Stato.

Maine, H. S. (1861). Ancient Law: Its Connection with the Early History of Society, and Its Relations to Modern Ideas (p. 2). Repr. 1982, Birmingham, AL: The Legal Classic Library.

Maitland, F. W. (1908). The Constitutional History of England: A Course of Lectures (p. 198). Cambridge: Cambridge University Press.

Maitland, F. W. (1911). Why the History of English Law Is Not Written. In H. A. L. Fisher (Ed.), The Collected Papers of Frederic William Maitland (Vol. 1, p. 488). Cambridge: Cambridge University Press.

Markesinis, B. (2003). Comparative Law in the Courtroom and the Classroom: The Story of the Last Thirty-Five Years (pp. 62). Oxford and Portland, OR: Hart.

Mattei, U. (2011). The Comparative Jurisprudence of Schlesinger and Sacco: A Study in Legal Influence. In A. Riles (Ed.), Rethinking the Masters of Comparative Law (p. 239). Oxford and Portland, OR: Hart.

Pollock, F., \& Maitland, M. (1898). History of English Law (2nd ed., p. 207). Cambridge: Cambridge University Press.

Rheinstein, M. (1956). In Memory of Ernst Rabel. The American Journal of Comparative Law, 5, 185-196.

Riles, A. (1999). Wigmore's Treasure Box: Comparative Law in the Era of Information (p. 228). Paper 1036, Ithaca, NY: Cornell Law School.

Riles, A. (2001). Rethinking the Masters of Comparative Law (p. 2). Oxford and Portland, OR: Hart.

Riles, A. (2014). From Comparison to Collaboration: Experiments with a New Scholarly and Political Form. Law and Contemporary Problems, 77, 1-25.

Sacco, R. (1991). Legal Formants: A Dynamic Approach to Comparative Law (Installment I of II). American Journal of Comparative Law, 39, 1-34. http://dx.doi.org/10.2307/840669

Sarfatti, M. (1933). Introduzione allo studio del diritto comparato [Introduction to the Study of Comparative Law] (p. 2). Turin: Giappichelli.

Scarciglia, R. (2015). Comparative Methodology and Pluralism in Legal Comparison in a Global Age. Beijing Law Review, 6 , 42-48. http://dx.doi.org/10.4236/blr.2015.61006

Stevens, L. C. (1954). The Contribution of French Jurists to the Humanism of the Renaissance. Studies in the Renaissance, 1, 92-105. http://dx.doi.org/10.2307/2856954 
Van Caenegem, R. C. (1987). Judges, Legislators and Professors: Chapters in European Legal History (p. 58). Cambridge: Cambridge University Press. http://dx.doi.org/10.1017/cbo9780511599361

Verger, J. (1999). Les gens de savoir dans l'Europe de la fin du Moyen Age [Men of Learning in Europeat the End of the Middle Ages] (p. 70). Paris: PUF.

Yntema, H. E. (1958). Comparative Law and Humanism. American Journal of Comparative Law, 7, 493-499. http://dx.doi.org/10.2307/837261

Zucca, L. (2009). Montesquieu, Methodological Pluralism and Comparative Constitutional Law. European Constitutional Law Review, 5, 481-500. http://ssrn.com/abstract=1512494 http://dx.doi.org/10.1017/s1574019609004817 